\title{
Front Matter: Volume 9610
}

, "Front Matter: Volume 9610," Proc. SPIE 9610, Remote Sensing and Modeling of Ecosystems for Sustainability XII, 961001 (24 September 2015); doi: $10.1117 / 12.2218010$

EDent: SPIE Optical Engineering + Applications, 2015, San Diego, California, SPIE. United States 


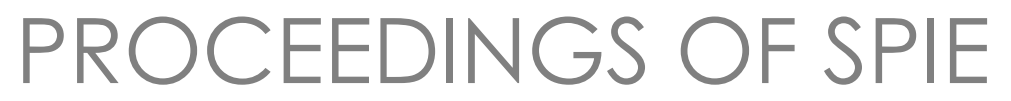

\title{
Remote Sensing and Modeling of Ecosystems for Sustainability XII
}

\author{
Wei Gao \\ Ni-Bin Chang \\ Editors
}

11-12 August 2015

San Diego, California, United States

Sponsored and Published by

SPIE 
The papers in this volume were part of the technical conference cited on the cover and title page. Papers were selected and subject to review by the editors and conference program committee. Some conference presentations may not be available for publication. Additional papers and presentation recordings may be available online in the SPIE Digital Library at SPIEDigitallibrary.org.

The papers reflect the work and thoughts of the authors and are published herein as submitted. The publisher is not responsible for the validity of the information or for any outcomes resulting from reliance thereon.

Please use the following format to cite material from these proceedings:

Author(s), "Title of Paper," in Remote Sensing and Modeling of Ecosystems for Sustainability XII, edited by Wei Gao, Ni-Bin Chang, Proceedings of SPIE Vol. 9610 (SPIE, Bellingham, WA, 2015) Sixdigit Article CID Number.

ISSN: 0277-786X

ISSN: 1996-756X (electronic)

ISBN: 9781628417760

Published by

SPIE

P.O. Box 10, Bellingham, Washington 98227-0010 USA

Telephone +1 3606763290 (Pacific Time) · Fax +1 3606471445

SPIE.org

Copyright (c) 2015, Society of Photo-Optical Instrumentation Engineers.

Copying of material in this book for internal or personal use, or for the internal or personal use of specific clients, beyond the fair use provisions granted by the U.S. Copyright Law is authorized by SPIE subject to payment of copying fees. The Transactional Reporting Service base fee for this volume is $\$ 18.00$ per article (or portion thereof), which should be paid directly to the Copyright Clearance Center (CCC), 222 Rosewood Drive, Danvers, MA 01923. Payment may also be made electronically through CCC Online at copyright.com. Other copying for republication, resale, advertising or promotion, or any form of systematic or multiple reproduction of any material in this book is prohibited except with permission in writing from the publisher. The CCC fee code is 0277-786X/15/\$18.00.

Printed in the United States of America.

Publication of record for individual papers is online in the SPIE Digital Library.

\section{SPIE. DIGITAL}

Paper Numbering: Proceedings of SPIE follow an e-First publication model, with papers published first online and then in print. Papers are published as they are submitted and meet publication criteria. A unique citation identifier (CID) number is assigned to each article at the time of the first publication. Utilization of CIDs allows articles to be fully citable as soon as they are published online, and connects the same identifier to all online, print, and electronic versions of the publication. SPIE uses a six-digit CID article numbering system in which:

- The first four digits correspond to the SPIE volume number.

- The last two digits indicate publication order within the volume using a Base 36 numbering system employing both numerals and letters. These two-number sets start with 00, 01, 02, 03, 04, $05,06,07,08,09,0 A, 0 B \ldots$. 0Z, followed by 10-1Z, 20-2Z, etc.

The CID Number appears on each page of the manuscript. The complete citation is used on the first page, and an abbreviated version on subsequent pages. 


\title{
Contents
}

\author{
vii Authors \\ ix Conference Committee
}

\section{SESSION 1 ENVIRONMENTAL REMOTE SENSING AND GIS}

961002 Site suitability evaluation for ecotourism potential areas using RS and GIS: a case study of Wadi Wurayah, Fujairah, UAE (Invited Paper) [9610-1]

961003 Evaluations of CMIP5 simulations over cropland (Invited Paper) [9610-2]

961004 Combined UV irradiance from TOMS-OMI satellite and UVMRP ground measurements across the continental U.S. (Invited Paper) [9610-3]

961006 Continuous evaluation of land cover restoration of tsunami struck plains in Japan by using several kinds of optical satellite image in time series [9610-5]

961007 In situ hyperspectral data analysis for canopy chlorophyll content estimation of an invasive species spartina alterniflora based on PROSAlL canopy radiative transfer model [9610-6]

\section{SESSION 2 REMOTE SENSING FOR AGRICULTURE, ECOSYSTEMS, AND HYDROLOGY}

9610 OB Land cover fraction estimation with global endmembers using collaborative SUnSAL [9610-12]

$96100 \mathrm{C}$ Effects of bias in solar radiation inputs on ecosystem model performance [9610-13]

$96100 \mathrm{OE}$ Using artificial neural network and satellite data to predict rice yield in Bangladesh [9610-15]

9610 OF Influence of canopy biochemical and biophysical variables on reflectance spectra based on canopy radiative transfer model with adding noise [9610-16]

9610 OG A study on China's LUCC and carbon-sink response with remote sensing [9610-18]

\section{SESSION 3 REMOTE SENSING AND MODELING APPLICATIONS}

9610 ol Impacts of global non-leading teleconnection signals on terrestrial precipitation across the United States (Invited Paper) [9610-19]

9610 0J Climate change impacts on the U.S. agricultural economy (Invited Paper) [9610-20] 
$96100 \mathrm{~K}$ Temporal variation (seasonal and inter-annual) of vegetation indices of maize and soybeans across multiple years in central lowa [9610-21]

9610 OL Two-stage reference channel calibration for collocated UV and VIS Multi-Filter Rotating Shadowband Radiometers [9610-22]

$96100 \mathrm{M}$ Water stress detection of lilac leaves using a polarized laser [9610-23]

9610 ON Raman spectroscopy for the control of the atmospheric bioindicators [9610-24]

961000 Study of emissivity changes presented by inorganic and organic soil under drying at ambient temperature [9610-25]

9610 OP A new method to classify hyperspectral data of Landsat TM image [9610-26]

\section{POSTER SESSION}

9610 OR Evaluation of WRF microphysics and cumulus parameterization schemes in simulating a heavy rainfall event over Yangtze River delta [9610-29]

9610 OT A tool for NDVI time series extraction from wide-swath remotely sensed images [9610-31]

$9610 \mathrm{OU}$ Detecting harmful algal blooms using Geostationary Ocean Color Imager $(\mathrm{GOCl})$ data in Bohai Sea, China [9610-32]

9610 oW Salinity and soil moisture retrieval algorithms in western Jilin Province of China using passive microwave remote sensing data [9610-34]

$96100 X$ Dynamic analysis on coastline and sea reclamation in the efficient ecological economic zone of the Yellow River Delta based on 30-years satellite data [9610-35]

9610 oY Snow depth retrieval algorithm of saline-alkali land in the western Jilin Province of China using passive microwave remote sensing data [9610-36]

$96100 Z$ Study on coastline change in Shandong Province based on geo-information TuPu [9610-37]

961010 Scaling effect on the estimation of chlorophyll content using narrow band NDVIs based on radiative transfer model [9610-38]

961011 Retrieval of aerosol optical depth over Beijing using Landsat8/OLI data [9610-39]

961012 Comparative analysis of land surface emissivity retrieval methods and the impact on the land surface temperature based on Landsat-8 thermal infrared data [9610-40] 
961013 Sensitivity of the reference evapotranspiration to key climatic variables in Shandong Province, China [9610-41]

961014 Validation of the OMI-TOMS and OMI-DOAS total ozone column data using ground-based observations over China [9610-42]

961015 Remote estimation of GPP in temperate grassland: implications of the uncertainty in GPP estimation in semi-arid ecosystems using MODIS data [9610-43]

961017 Simulation and analysis of NDVI performance based on vegetation canopy radiative transfer model [9610-45]

961018 Changes on albedo after a large forest fire in Mediterranean ecosystems [9610-46]

$96101 \mathrm{~A}$ Data fusion of $\mathrm{CO}_{2}$ retrieved from GOSAT and AIRS using regression analysis and fixed rank kriging [9610-48]

9610 1B The estimation of Aerosol Optical Depth in eastern China based on regression analysis [9610-49]

9610 1C Optical methods for control of heavy metals impact on aquatic plants [9610-50]

9610 1D Retrieval of water and heat flux based on fusion of LANDSAT TM/ETM+ and MODIS data [9610-51] 
Proc. of SPIE Vol. $9610961001-6$

Downloaded From: https://www.spiedigitallibrary.org/conference-proceedings-of-spie on 26 Apr 2023 Terms of Use: https://www.spiedigitallibrary.org/terms-of-use 


\section{Authors}

Numbers in the index correspond to the last two digits of the six-digit citation identifier (CID) article numbering system used in Proceedings of SPIE. The first four digits reflect the volume number. Base 36 numbering is employed for the last two digits and indicates the order of articles within the volume. Numbers start with 00, 01, 02, 03, 04, 05, 06, 07, 08, 09, 0A, 0B...0Z, followed by 10-1Z, 20-2Z, etc.

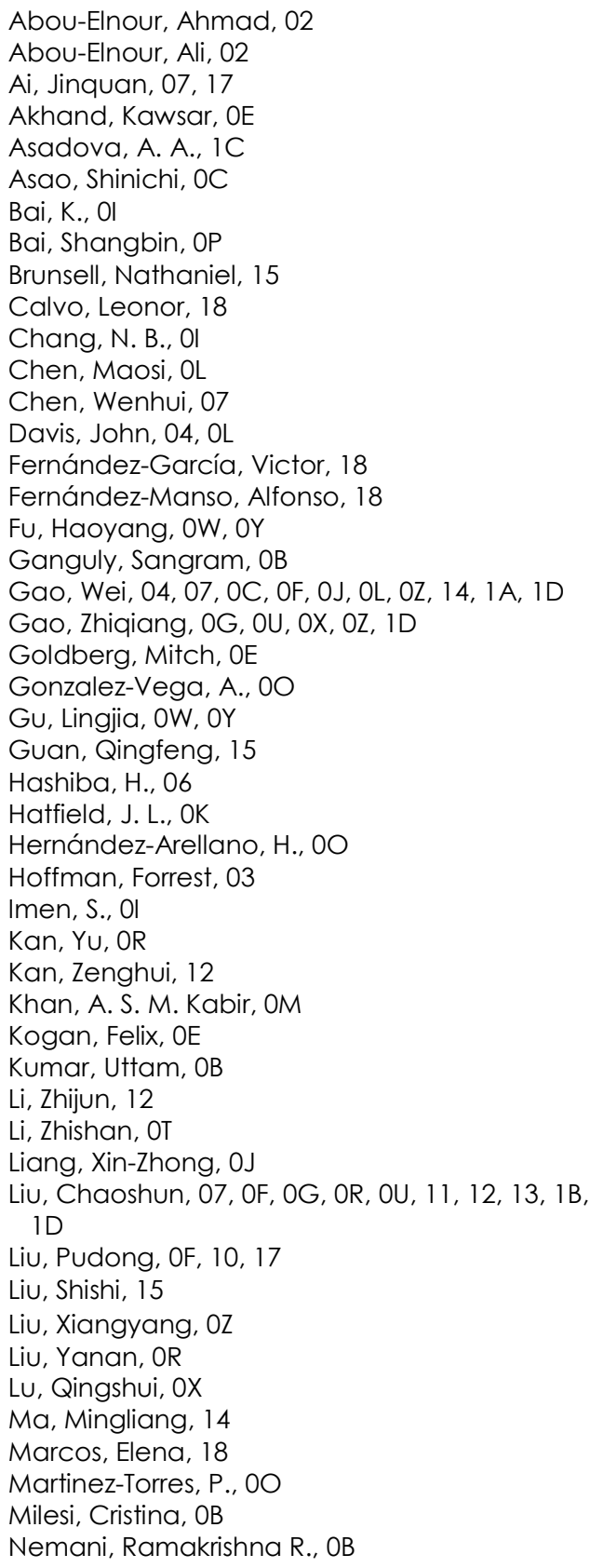

Ning, Jicai, OG, OX, OZ, 1D

Nizamuddin, Mohammad, OE

Pallathucheril, Varkki, 02

Peng, Yi, 15

Prueger, J. H., OK

Quintano, Carmen, 18

Raja, S. Kumar, OB

Ren, Ruizhi, OW, OY

Roytman, Leonid, OE

Shamina, L. A., ON

Shi, Runhe, 07, OF, OT, 10, 11, 14, 17, 1A, 1B

Sun, Mingbo, OY

Sun, Zhibin, 04, 07, OC, OF, OL, OP

Tan, Songxin, $\mathrm{OM}$

Timchenko, E. V., ON, 1C

Timchenko, P. E., ON, 1C

Tregub, N. V., 1C

Villaseñor-Mora, C., 00

Wang, Hong, OF, 10

Wang, Jing, 1B

Wang, Weile, OB

Wang, Yixiang, $O P$

Wu, You, OJ

$X \cup, \operatorname{Min}, 03$

$\mathrm{Xu}$, Mingzhu, OU

Yang, Jialin, 13

Zeng, Yuyan, 07, 17

Zhang, Chao, 07

Zhang, LU, 11

Zheng, Xiangyu, OG, OX

Zherdeva, L. A., ON, $1 \mathrm{C}$

Zhou, Cong, OR, OT, 10, 11, 12, 13, 17, 1A, 1B 
Proc. of SPIE Vol. $9610961001-8$

Downloaded From: https://www.spiedigitallibrary.org/conference-proceedings-of-spie on 26 Apr 2023 Terms of Use: https://www.spiedigitallibrary.org/terms-of-use 


\section{Conference Committee}

Program Track Chair

Allen H.-L. Huang, University of Wisconsin-Madison (United States)

Conference Chairs

Wei Gao, Colorado State University (United States)

Ni-Bin Chang, University of Central Florida (United States)

Conference Co-chair

Jinnian Wang, Institute of Remote Sensing Applications (China)

Conference Program Committee

E. Raymond Hunt Jr., Agricultural Research Service (United States)

Brian Robert Johnson, Raytheon Company (United States)

Thomas U. Kampe, NEON, Inc. (United States)

Xin-Zhong Liang, University of Maryland, College Park (United States)

Dennis Ojima, Colorado State University (United States)

John J. Qu, George Mason University (United States)

David Riaño, University of California, Davis (United States)

Jiong Shu, East China Normal University (China)

Zhibin Sun, Colorado State University (United States)

Qiao Wang, Ministry of Environmental Protection (China)

Hongjie Xie, The University of Texas at San Antonio (United States)

Xiaobing Zhou, Montana Tech (United States)

\section{Session Chairs}

1 Environmental Remote Sensing and GIS

Zhibin Sun, Colorado State University (United States)

Ali Abou-Elnour, Ajman University of Science \& Technology

(United Arab Emirates)

2 Remote Sensing for Agriculture, Ecosystems, and Hydrology

$\mathrm{Ni}$-Bin Chang, University of Central Florida (United States)

Min Xu, Oak Ridge National Laboratory (United States)

3 Remote Sensing and Modeling Applications

Xin-Zhong Liang, University of Maryland, College Park (United States)

John H. Prueger, Agricultural Research Service (United States) 
Proc. of SPIE Vol. $9610961001-10$

Downloaded From: https://www.spiedigitallibrary.org/conference-proceedings-of-spie on 26 Apr 2023 Terms of Use: https://www.spiedigitallibrary.org/terms-of-use 